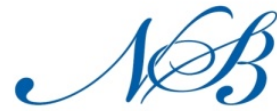

Notulae Scientia Biologicae

Original Article

\title{
Morphometric Study of Several Species of the Genus Jatropha Linn. (Euphorbiaceae)
}

\author{
Opeyemi Saheed KOLAWOLE ${ }^{1 *}$, \\ Abdullahi Alanamu ABDULRAHAMAN², Mahboob Adekilekun JIMOH², \\ Felix Ayotunde OLADELE ${ }^{4}$
}

\author{
${ }^{1}$ Federal University, Department of Biological Sciences, Kashere, Gombe State, Nigeria; kolawolesaheed@fukashere.edu.ng(*orrespondingauthor) \\ ${ }^{2}$ University of Ilorin,Department of Plant Biology, Ilorin,Nigeria; abdulrahamanaa@unilorin.edu.ng \\ ${ }^{3}$ Osun State University, Department of Biological Sciences, Osogbo, Nigeria;jimohmabboob@yahoo.co.uk \\ ${ }^{4}$ University ofIlorin,Department of Plant Biology, Ilorin, Nigeria; foladele@unilorin.edu.ng
}

\begin{abstract}
Morphological parameters of several Jatropha species, namely Jatropha curcas L., Jatropha gossypifolia L., Jatropha podagrica Hook., Jatropha integerrima Jacq. and Jatropha multifida L. were subjected to quantitative analysis within the present study. Twelve traits of the leaves, fruits and seeds were analysed: leaf length, leaf width, leaf length/width ratio, petiole length, petiole width, fruit length, fruit width, fruit length/width ratio, seed length, seed width, fruit stalk length and fruit stalk width were subjected to Principal Component Analysis (PCA) and cluster analysis. Highly significant positive correlations have been noted, while negative correlation was observed between leaf width and leaf length/width ratio, fruit width and leaf length/width ratio. Traits such as leaf length, leaf width and leaf length/width ratio contributed significantly along with other traits to discriminate the studied Jatropha species. J. podagrica and J. integerrima were found to have more similarities, with a stronger coefficient of agglomeration (69.072) than J. curcas and J. podagrica with 315.028 coefficient of agglomeration respectively. The generated dendrogram showed the relationship between the studied Jatropha species, whereas great affinity was noted between J. podagrica and J. multifida as compared with J. gossypifolia and J. integerrima which are distantly related. The closeness observed between J. podagrica and J. multifida is in line with their current sub-generic grouping.
\end{abstract}

Keywords: cluster analysis, fruits, Jatropha species, leaves, PCA, seeds, taxonomy

\section{Introduction}

Jatropha L. is a morphologically diverse and geographically widespread genus of 150-175 woody species (Dehgan, 1982). The genus Jatropha belongs to the family Euphorbiaceae and is a very diverse subtropics and tropical genus which includes succulent, caudiciform species, herbaceous perennial and woody species (Nwokocha et al., 2011).

Hutchinson and Dalziel (1958) recognized 8 species of Jatropha in West-Tropical Africa, while Ratha and Paramathma (2009) described 12 species of Jatropha in India, using morphological traits. A range of economic importance of Jatropha species has been reported, most especially J. curcas yields oil of highly marketable biodiesel value (Agarwal and Agarwal, 2007; Akbar et al., 2009). The oil is used in the manufacture of candle, soap and cosmetics industry (Nwokocha et al., 2011). J. curcas also has a great potentiality in the rehabilitation of degraded soil (Achten et al., 2007; Damisa et al., 2008; Kumar et al., 2008; Koyejo et al., 2010) and it is a drought resistant plant that has wide adaptability to varied climate and soils. In addition, J. podagrica Hook. seeds yield $40 \%$ of oil known as pinheon oil or "oil infernale" (Joubert et al., 1984).J. integerrima Jacq. makes a delightful shrubs border plant with its eye catching red flowers (Oladipo and Illoh, 2012) and it contains a potential lethal toxin called curcin. A leaf decoction of J. gossypifolia is used routinely by herbalists in the urban areas to stop nose, gum and skin bleeding. Further, leaf decoction of J. gossypifolia has been used for bathing wounds, while its seeds are used as purgative and for treatment of body aches.

Morphometrics represent the quantitative analysis of biological form that has been widely used in a lot of discipline including systematics (Henderson, 2006). Morphometrics, known as numerical taxonomy, is the application of various mathematical procedures to encode characters. The practice of numerical taxonomy embraces numbers of fundamental assumptions and philosophical attitudes towards taxonomic work. It has the ability to integrate data from a variety of sources such as anatomy, cytology, ecology, genetics, geography, physiology, palynology, chemistry etc. (Soladoye $e t$ al., 2010b). 
212

The products of such determinations are often considered to be unbiased indicators of the similarity or differences between the taxa, which are used to arrange taxa in hierarchy (Quike, 1993). The method of morphometrics or numerical taxonomy has been used in classifying many plants, as well as interpreting results of the taxonomic studies (Sonibare et al., 2004; Abu Zaida et al., 2008; ElGazzar, 2008; Soladoye et al., 2010b).

The present study has therefore aimed at using the morphometrics method to observe the differences and similarities in the morphological characters used to discriminate Jatropha species. The objective of the study is to determine the traits that would contributed strongly to the delimitation of the taxa based on their similarities.

\section{Materials and Methods}

\section{Plant collection}

Mature plant specimens from the field and herbarium were used for the study. The fresh specimens were collected in open vegetation, from roadsides and bushy areas in various parts of South-Western Nigeria, while herbarium specimens were accessions previously collected from different parts of Nigeria and preserved in the Forest Herbarium, Ibadan, FHI, Nigeria (Table 1). Upon collection of fresh plants, voucher specimens were prepared according to the established protocol of Soladoye et al. (2010a).

In this study, twenty-five accessions of each species were examined. Some traits which were difficult to assess accurately or were unsuitable for rapid and accurate scoring were eliminated. Thus, twelve traits were recorded as employed for the morphometric study: leaf length and width, leaf length/ width, petiole length, petiole width, fruit length, fruit length/width, seed length, seed width, fruit stalk length and fruit stalk width.

\section{Morphometric and statistical analysis}

Morphometric analysis was carried out on field and on herbarium specimens of each of the five species of the genus Jatropha. The measurements regarded the length and width of leaves, petiole, fruit, seed and fruit stalk using a line ruler and an electronic digital calliper graduated in millimetres (later converted to centimetres). The length of the leaf was obtained by spreading on a white sheet of paper on the laboratory bench and the longest part was measured; the same procedure was used for the width of vegetative parts. These measurements were then compiled for each Operational Taxonomic Unit (OTU).

Table 1. Voucher information and distribution of fresh and herbarium specimens of studied Jatropha species

\begin{tabular}{lc}
\hline Plant species & Herbarium specimen \\
\hline Jatropha curcas L. & FHI 108927, FHI 109620, FHI \\
& 109865, FHI 86744, FHI 108432 \\
Jatropha gossypifolia L. & FHI 108011, FHI 108195, FHI \\
& 83442, FHI 44937, FHI 109863 \\
Jatropha podagrica Hook. & FHI 107676, FHI 64394, FHI \\
Jatropha integerrima Jacq. & 14509, FHI 43496, FHI 109871 \\
Jatropha multifilda L. & FHI 109864, IFE 16420 \\
\hline
\end{tabular}

The corresponding mean figures of the recorded measurements keyed into a Microsoft Excel spreadsheet and SPSS 16.0 statistical software analysis sheet. The Principal Components Analysis (PCA) and Cluster Analysis were computed based on the 12 selected quantitative traits measured.

\section{Results}

Morphological parameters of five Jatropha species (Table 1) were examined with numerical methods. The mean and standard deviation of the quantitative morphological traits employed are presented in Table 2. Similarities matrix on correlation of Jatropha species (Table 3 ) showed that close resemblance of species could be observed when certain characters are employed. For instance, when leaf length was correlated with leaf width, the degree of affinity was 0.816 and 0.338 when correlated with petiole width, but when leaf length was correlated against leaf length, it was 1,000 . Similarly, when leaf width was correlated with leaf length/width ratio, the degree of resemblance was -0.317 , whereas it was 0.380 when compared with fruit width and 1.000 when correlated against fruit width. The results revealed highly significant positive correlations among almost all the analysed traits. Negative correlation was observed between leaf width and leaf length/width ratio, fruit width and leaf length/width ratio.

The cumulative Principal Component Analysis is presented in Table 4. At least three of the traits (leaf length, leaf width and leaf length/width ratio) contributed greatly to the delimitation of the studied taxa.

Differences based on morphometry of Jatropha species are noted in Table 5, representing the agglomeration schedule of the studied Jatropha species as viewed from the perspective of cluster.

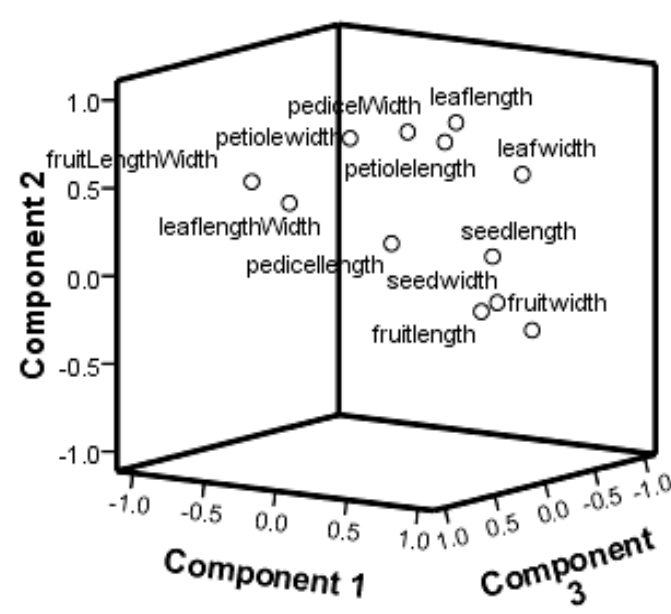

Fig. 1. Component plot in rotated space for the twelve morphological traits examined among Jatropha species; Component 1: petiole width; Component 2: fruit length/ width; Component 3: leaf length/ width 
Table 2. Quantitative traits of Jatropha species scored for leaves, petiole, seeds and fruits

\begin{tabular}{|c|c|c|c|c|c|c|c|c|c|c|c|c|}
\hline Plantspecies & $\begin{array}{l}\text { Leaflength } \\
(\mathrm{mm})\end{array}$ & $\begin{array}{l}\text { Leafwidth } \\
\text { (mm) }\end{array}$ & $\begin{array}{c}\text { Leaf } \\
\text { length/width }\end{array}$ & $\begin{array}{l}\text { Petiole } \\
\text { length } \\
(\mathrm{cm})\end{array}$ & $\begin{array}{l}\text { Petiole } \\
\text { width } \\
(\mathrm{cm})\end{array}$ & $\begin{array}{l}\text { Fruitlength } \\
(\mathrm{cm})\end{array}$ & $\begin{array}{l}\text { Fruit width } \\
(\mathrm{cm})\end{array}$ & $\begin{array}{c}\text { Fruit } \\
\text { length/width }\end{array}$ & $\begin{array}{l}\text { Seed } \\
\text { length } \\
(\mathrm{cm})\end{array}$ & $\begin{array}{l}\text { Seedwidth } \\
(\mathrm{cm})\end{array}$ & $\begin{array}{l}\text { Fruitstallk } \\
\text { length } \\
(\mathrm{cm})\end{array}$ & $\begin{array}{c}\text { Fruitstalk } \\
\text { width } \\
(\mathrm{cm})\end{array}$ \\
\hline $\begin{array}{l}\text { Jatrophacurcas } \\
\text { L. }\end{array}$ & $14.34 \pm 214$ & $1371 \pm 252$ & $15.65 \pm 3.95$ & $15.65 \pm 0.12$ & $0.310 \pm 0.06$ & $287 \pm 0.21$ & $259 \pm 0.24$ & $1.11 \pm 0.051$ & $1.60 \pm 0.149$ & $1.10 \pm 0.138$ & $371 \pm 216$ & $0294 \pm 0.10$ \\
\hline $\begin{array}{l}\text { Jatropha } \\
\text { gosspifolia L. }\end{array}$ & $8.04 \pm 2.16$ & $10.0 \pm \pm 23$ & $0.80 \pm 0.050$ & $7.51 \pm 230$ & $0.44 \pm 0.27$ & $1.39 \pm 0.31$ & $1.408 \pm 0.34$ & $0.98 \pm 0.13$ & $0.62 \pm 0.02$ & $0.41 \pm 0.08$ & $0.89 \pm 0.30$ & $0.52 \pm 0.20$ \\
\hline $\begin{array}{l}\text { Jatropha } \\
\text { podagrica Hook. }\end{array}$ & $21.62 \pm 4.48$ & $2232 \pm 4930$ & $0.975 \pm 0.06$ & $20.49 \pm 3.05$ & $0.771 \pm 0.27$ & $1.763 \pm 0.17$ & $1.52 \pm 0.19$ & $1.17 \pm 0.06$ & $120 \pm 039$ & $0.642 \pm 024$ & $226 \pm 0.92$ & $0.97 \pm 0.04$ \\
\hline $\begin{array}{l}\text { Jatropha } \\
\text { integerrimaJacq. }\end{array}$ & $13.04 \pm 234$ & $9.80 \pm 3326$ & $1.461 \pm 0.47$ & $9.037 \pm 256$ & $0.204 \pm 0.05$ & $1.83 \pm 0.02$ & $1.84 \pm 0.03$ & $1.19 \pm 0.02$ & $0.58 \pm 0.02$ & $038 \pm 0.03$ & $0.45 \pm 0.01$ & $0.12 \pm 0.02$ \\
\hline $\begin{array}{l}\text { Jatropha } \\
\text { multifilda } \mathrm{L} \text {. }\end{array}$ & $15.58 \pm 1.42$ & $2425 \pm 263$ & $0.646 \pm 0.056$ & $15.32 \pm 2.42$ & $0.281 \pm 0.10$ & $2814 \pm 0.22$ & $1.78 \pm 1.55$ & $0.947 \pm 0.34$ & $1.63 \pm 0.534$ & $128 \pm 0.036$ & $209 \pm 026$ & $0.79 \pm 0.01$ \\
\hline
\end{tabular}

Table 3. Correlation matrix based on quantitative traits of the studied Jatropha species

\begin{tabular}{|c|c|c|c|c|c|c|c|c|c|c|c|c|}
\hline Traits & $\begin{array}{l}\text { Leaf } \\
\text { length }\end{array}$ & Leafwidth & $\begin{array}{c}\text { Leaf } \\
\text { length/ } \\
\text { width }\end{array}$ & $\begin{array}{l}\text { Petiole } \\
\text { length }\end{array}$ & $\begin{array}{l}\text { Petiole } \\
\text { width }\end{array}$ & $\begin{array}{l}\text { Fruit } \\
\text { length }\end{array}$ & $\begin{array}{l}\text { Fruit } \\
\text { width }\end{array}$ & $\begin{array}{c}\text { Fruit } \\
\text { length/ } \\
\text { width }\end{array}$ & $\begin{array}{l}\text { Seed } \\
\text { length }\end{array}$ & $\begin{array}{l}\text { Seed } \\
\text { width }\end{array}$ & $\begin{array}{c}\text { Fruit } \\
\text { stalk } \\
\text { length }\end{array}$ & $\begin{array}{c}\text { Fruit } \\
\text { stalk } \\
\text { width }\end{array}$ \\
\hline Leaflength & 1.000 & & & & & & & & & & & \\
\hline Leaf width & $0.816^{\mathrm{ab}}$ & 1.000 & & & & & & & & & & \\
\hline Leaflength/width & $0.258^{\mathrm{a}}$ & $-0.317^{\mathrm{ab}}$ & 1.000 & & & & & & & & & \\
\hline Petiolelength & $0.671^{\mathrm{ab}}$ & $0.553^{\mathrm{ab}}$ & $0.187^{\mathrm{a}}$ & 1.000 & & & & & & & & \\
\hline Petiolewidth & $0.338^{\mathrm{ab}}$ & 0.129 & $0.240^{\mathrm{a}}$ & $0.352^{\mathrm{ab}}$ & 1.000 & & & & & & & \\
\hline Fruit length & 0.158 & $0.287^{\mathrm{ab}}$ & 0.017 & $0.240^{\mathrm{a}}$ & $-0.401^{\mathrm{ab}}$ & 1.000 & & & & & & \\
\hline Fruit width & 0.033 & $0.380^{\mathrm{ab}}$ & $-0.483^{\mathrm{ab}}$ & 0.006 & $-0.325^{\mathrm{ab}}$ & $0.448^{\mathrm{ab}}$ & 1.000 & & & & & \\
\hline Fruit length/width & 0.150 & $-0.268^{a b}$ & $0.613^{\mathrm{ab}}$ & 0.135 & $0.377^{\mathrm{ab}}$ & $-0.357^{\mathrm{ab}}$ & $-0.947^{\mathrm{ab}}$ & 1.000 & & & & \\
\hline Seedlength & $0.445^{\mathrm{ab}}$ & $0.522^{\mathrm{ab}}$ & 0.071 & $0.470^{\mathrm{ab}}$ & $-0.266^{\mathrm{ab}}$ & $0.889^{\mathrm{ab}}$ & $0.383^{\mathrm{ab}}$ & $-0.238^{a}$ & 1.000 & & & \\
\hline Seed width & $0.224^{a}$ & $0.415^{\mathrm{ab}}$ & -0.092 & $0.270^{\mathrm{ab}}$ & $-0.420^{\mathrm{ab}}$ & $0.915^{\mathrm{ab}}$ & $0.484^{\mathrm{b}}$ & $-0.391^{b}$ & $0.929^{\mathrm{ab}}$ & 1.000 & & \\
\hline Fruit stalk length & $0.241^{\mathrm{a}}$ & 0.085 & $0.348^{\mathrm{ab}}$ & $0.283^{\mathrm{ab}}$ & -0.059 & $0.469^{\mathrm{ab}}$ & -0.010 & 0.129 & $0.502^{\mathrm{ab}}$ & $0.424^{\mathrm{ab}}$ & 1.000 & \\
\hline Fruit stalk width & $0.527^{\mathrm{ab}}$ & $0.422^{\mathrm{ab}}$ & 0.010 & $0.370^{\mathrm{ab}}$ & $0.580^{\mathrm{ab}}$ & $-0.459^{a b}$ & -0.091 & 0.127 & $-0.208^{a}$ & $-0.373^{\mathrm{ab}}$ & -0.140 & 1.000 \\
\hline
\end{tabular}

Superscript a represents significantly different at $\mathrm{P}<0.05$; Superscript $\mathbf{b}$ represents significantly different at $\mathrm{P}<0.01$

Rescaled Distance Cluster Combine

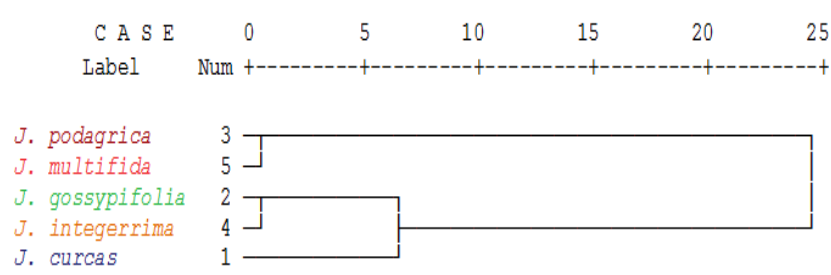

Fig. 2. Cluster analysis showing the relationship among Jatropha species based on quantitative morphological traits [Using Average Linkage]

The cluster that exists between species 3 (J. podagrica) and species 5 (J. multifida) had a coefficient of 69.072, whereas between species 1 ( $J$. curcas) and species $3(J$. podagrica) it was 315.025 , showing a great degree of variation within their morphometry.

Table 6 showed the factor loading of the twelve quantitative morphological characters and it also reveals that some traits are more valuable comparing with others in the genus variation. Fig. 1 shows the components plots on rotated axis for the twelve quantitative morphological traits employed; it was noted that petiole width, fruit length/width and leaf length/width were contributing most to the separation among species.

The dendrogram showing the relationships established among the studied species, based on the quantitative morphological characters within the study, underlined a great affinity that exists between J. podagrica
Table 5. Agglomeration schedule of the Jatropha species as viewed from the perspective of clusters

\begin{tabular}{cccccccc}
\hline \multirow{2}{*}{ Stage } & \multicolumn{2}{c}{ Clustercombined } & & & \multicolumn{2}{c}{$\begin{array}{c}\text { Stagedustersfirst } \\
\text { appears }\end{array}$} & \multirow{2}{*}{$\begin{array}{c}\text { Next } \\
\text { stage }\end{array}$} \\
\cline { 2 - 3 } \cline { 5 - 6 } & Cluster1 & Cluster2 2 & & Cluster 1 & Cluster2 & \\
\hline 1 & 3 & 5 & 69.072 & 0 & 0 & 4 \\
2 & 2 & 4 & 71.562 & & 0 & 3 \\
3 & 1 & 2 & 129.327 & 0 & 2 & 4 \\
4 & 1 & 3 & 315.025 & 3 & 1 & 0 \\
\hline
\end{tabular}

Note: 1. J. curcas L.; 2. J. gossypifolia L.; 3. J. podagrica Hook.; 4. J. integerrima Jacq.; 5. J. multifilda L.

Table 6. Factor loading of the Jatropha species quantitative traits

\begin{tabular}{lccc}
\hline Component & \multicolumn{3}{c}{ Components } \\
\cline { 2 - 4 } Matrix & 1 & 2 & 3 \\
\hline Leaf length & 0.669 & -0.063 & 0.688 \\
Leaf width & 0.860 & -0.386 & 0.063 \\
Leaf length/width & -0.550 & 0.494 & 0.656 \\
Petiole length & 0.859 & -0.147 & 0.489 \\
Petiole width & 0.270 & -0.734 & 0.479 \\
Fruit length & 0.734 & 0.623 & -0.215 \\
Fruit width & 0.330 & 0.920 & 0.062 \\
Fruit length/width & -0.329 & 0.459 & 0.825 \\
Seed length & 0.960 & 0.255 & -0.115 \\
Seed width & 0.880 & 0.344 & -0.315 \\
Fruit stalk length & 0.815 & 0.370 & 0.088 \\
Fruit stalk width & 0.627 & -0.778 & 0.037 \\
\hline Extraction method. Princip. & Component Anlysis. 3 components (studied
\end{tabular}

Extraction method: Principal Component Analysis; 3 components (studied traits) extracted: petiole width, fruit length/width and leaf length/width

and J. multifida opposite to the one between $J$. gossypifolia and $J$. integerrima which were distantly related (Fig. 2). 
Table 4. Variance in the observed traits using Principal Component Analysis

\begin{tabular}{|c|c|c|c|c|c|c|}
\hline \multirow{2}{*}{ Trait (Component) } & \multicolumn{3}{|c|}{ Initial Eigen values } & \multicolumn{3}{|c|}{ Extraction sums of squared loadings } \\
\hline & Total & $\%$ of Variance & Cumulative \% & Total & $\%$ of Variance & Cumulative $\%$ \\
\hline 1 & 4.329 & 36.072 & 36.072 & 43.29 & 36.072 & 36.072 \\
\hline 2 & 3.140 & 26.169 & 62.241 & 3.140 & 26.169 & 62.241 \\
\hline 3 & 2.211 & 18.427 & 80.668 & 2.211 & 18.427 & 80.668 \\
\hline 4 & 0.640 & 5.334 & 86.003 & & & \\
\hline 5 & 0.500 & 4.166 & 90.169 & & & \\
\hline 6 & 0.471 & 3.924 & 94.093 & & & \\
\hline 7 & 0.339 & 2.825 & 96.913 & & & \\
\hline 8 & 0.237 & 1.977 & 98.895 & & & \\
\hline 9 & 0.074 & 0.615 & 99.511 & & & \\
\hline 10 & 0.32 & 0.204 & 99.775 & & & \\
\hline 11 & 0.022 & 0.179 & 99.954 & & & \\
\hline 12 & 0.005 & 0.046 & 100.00 & & & \\
\hline
\end{tabular}

\section{Discussion}

Generally, morphometrics add a quantitative element to species descriptions, allowing more rigorous comparisons within a genus. In the numerical analysis of five Jatropha species using twelve quantitative morphological traits, the results revealed that variations in the vegetative parts and fruit traits are important. Of the quantitative parameters used, leaf length, leaf width and leaf length/width ratio had the highest values compared with the others traits, confirming their usefulness for species identification purposes. Same trends had been observed by previous studies on Ficus species (Sonibare et al., 2004), Acalypha in SouthWestern Nigeria (Soladoye et al., 2008), Senna species in South-Western Nigeria (Soladoye et al., 2010a) and Indigofera species (Soladoye et al., 2010b).

The studied Jatropha species exhibited variations based on samples collected from different locations. The size of the fruit and bud length was dependent on the age of plants as earlier confirmed by other reports (Irvine, 1961; Burkill, 1995). Leaf shape and size may vary within the same plant. Previous studies suggested that light intensity may affect the carbohydrate balance, which could affect the length of the cells in the direction of the long axis, thereby leading to differences in the length, shapes and width of the leaves (Soladoye et al., 2010b). Such variations observed may be due to environmental, as well as genetic factors, and the interaction among them (Nwachukwu and Mbagwu, 2006).

The closeness observed between $J$. podagrica and $J$. multifida is in line with their current subgeneric and sectional delimitations based on their vegetative morphology, epidermal and petiole anatomy (Dehgan and Webster, 1979; Dehgan, 1980, 1982). Both species belong to the subgenus Jatropha, section Peltatae. Generally, the pattern of clustering observed in dendogram using average linkage within groups was in line with the current sub generic delimitation of the taxa. Under the current classification, only J. curcas belongs to the subgenus Curcas, while the remaining taxa belong to the subgenus Jatropha. In the dendogram it can be observed that there was a close relationship between $J$. gossypifolia and $J$. integerrima in their quantitative morphological traits, although they have different sectional delimitation in taxonomy (Dehgan and Webster, 1979; Dehgan, 1980, 1982); nevertheless, Oladipo and Illoh (2012) on their research on the comparative wood anatomy on genus Jatropha underlined same findings as the current study did.

The chemotaxonomic method of using quantitative phytochemical constituent differences can also be employed in further investigation on the taxonomy of the genus Jatropha, thereby adding to the existing information on the taxonomic results of stomata parameters (Abdulrahaman and Oladele, 2010), leaf electrophoresis (Oladipo and Illoh, 2012), crude seed electrophoresis (Oladipo et al., 2008) and wood anatomy (Oladipo and Illoh, 2012) on the genus Jatropha.

\section{Conclusions}

Conclusively, numerical taxonomy provided a greater discrimination along the spectrum of taxonomic differences among Jatropha species and was also more sensitive in the delimitation of the studied taxa. The closeness observed between J. podagrica and J. multifida is in agreement with their current sub-generic grouping. In addition, the study hereby revealed more detailed information on the level of relationship within the genus Jatropha.

\section{References}

Abdulrahaman AA, Oladele FA (2010). Stomatal complex types, stomatal density and stomatal index in some Jatropha species L. (Euphorbiaceae). Nigerian Journal of Pure and Applied Sciences 23:2160-2163.

Abu Zaida ME, Mashaly IA, Torky M (2008). Ecological studies on the aquatic vegetation in North East Nile Delta, Egypt. International Journal Botany 4:151-163.

Achten WMJ, Mathijs E, Verchot L, Singh VP, Aerts R, Muys B (2007). Jatropha biodiesel fueling sustainability? Biofuels, Bioproducts and Biorefining 1(4):283-291.

Agarwal D, Agarwal AK (2007). Performance and emissions characteristics of Jatropha oil (preheated and blends) in a direct 
injection compression ignition engine. Applied Thermal Engineering 27(13):2314-2323.

Agbagwa IO, Okoli BE (2005). Fruit epidermal micromorphology in the systematic of Abrus Adanson (Papilionaceae) in parts of West Africa. Asian Journal of Plant Science 4:652-659.

Akbar E, Yaakob Z, Kamarudin SK, Ismail M, Salimon J (2009). Characteristics and composition of Jatropha curcas oil seed from Malaysia and its potential as biodiesel feedstock. Eurasian Journal of Science Research 29:396-403.

Burkill HM (1995). The useful plants of West Tropical Africa, Vol 3 , 2nd ed. Royal Botanic Gardens, Kew, London.

Chiapella J (2000). The Deschampsia cespitosa complex in central and northern Europe: a morphological analysis. Botanical Journal of the Linnean Society 134(4):495-512.

Damisa D, Ameh JB, Umoh VI (2008). The effect of changes in management concentrations on cellulose yield from biogases fermented with mutagenised strain of Aspergilus niger AHZ. International Journal of Biological and Chemical Science 2(3):363-367.

Dehgan B (1980). Application of epidermal morphology to taxonomic delimitation in the genus Jatropha L. (Euphorbiaceae). Botanical Journal of Linnean Society 80:257-278.

Dehgan B (1982). Comparative anatomy of the petiole and infrageneric relationship in Jatropha (Euphorbiaceae). American Journal of Botany 69(8):1283-1295.

Dehgan B, Webster GL (1979). Morphology and infrageneric relationship of the genus Jatropha (Euphorbiaceae). University of California Publication Botany 74:1-73.

El-Gazzar A (2008). Taxonomic assessment of five numerical methods and its implications on the classification of Hyptis $\mathrm{L}$. (Labiatae). International Journal of Botany 4:85-92.

Gomez-Campo C, Herranz-Sanz JM, Montero-Riquelme FR (2001). The genus Coincya Rouy (Cruciferae) in South-Central Spain revisited: A morphometric analysis of population structure. Botanical Journal of Linnean Society 135:125-135.

Henderson A (2006). Traditional morphometrics in plant systematics and its role in palm systematics. Botanical Journal of the Linnean Society 151:103-111.

Hutchinson J, Dalziel JM (1958). Flora of West Tropical Africa, Vol 1, 2nd ed, Crown Agents for Oversea Governments and Administrations. Millbank, London, UK.

Irvine FR (1961). Woody plants of Ghana with special reference to their uses, 2nd ed. Oxford University Press, London.

Joubert PH, Brown JM, Hay IT, Sebata PD (1984). Acute poisoning with Jatropha curcas (purging nut tree) in children. South African Medical Journal 65:729-730.
Koyejo OA, Okonkwo HO, Akpan UF, Afolarin TA, Otorokpo A (2010). Harvesting, germination and early growth of Jatropha curcas. In: Akinlade JA, Ogunwale AB, Asaolu VO, Aderinola OA, Ojeiyi OO, Rafiu TA, Olayeni TB, Yekini DO (Eds). Proceedings of the 44th Annual Conference of the Agricultural Society of Nigeria (ASN), LAUTECH, Oyo State, Nigeria pp 1173-1175.

Kumar A, Ashwani CA, Satyawati S (2008). An evaluation of multipurpose oil seed crop for industrial uses (Jatropha curcas L.): A review. Industrial Crops and Products 1-8.

Nwachukwu CU, Mbagwu FN (2006). Morphological features in some species of Indigofera L. (Leguminosae-Papilionoideae). Journal Fisheries International 1:50-54.

Nwokocha AB, Agabagwa IO, Okoli BE (2011). Comparative phytochemical screening of Jatropha L. species in Niger Delta. Research Journal Phytochemistry 5:107-114.

Oladipo OT, Illoh HC, Odekanyin OO (2008). Crude protein electrophoresis of seeds of four Nigerian species of Jatropha Linn. (Euphorbiaceae). Ife Journal of Science 10(2):263-267.

Oladipo OT, Illoh HC (2012). Comparative wood anatomy of some members of the genus Jatropha (Euphorbiaceae) found in Nigeria. Phytologia Balcanica 18(2):141-147.

Quike DLJ (1993). Principles and techniques of contemporary taxonomy (Tertiary level biology), 1st ed. Kluwer Academic Publishers Norwell.

Ratha PK, Paramathma M (2009). Potentials and Jatropha species wealth of India. Current Science 97(7):1000-1004.

Sneath PHA, Sokal RR (1973). Numerical taxonomy: The principles and practice of numerical classification. Freeman and Co, San Francisco.

Soladoye MO, Sonibare MA, Rosanwo TO (2008). Phytochemical and morphometric analysis of the genus Acalypha Linn. (Euphorbiaceace). Journal of Applied Sciences 8:3044-3049.

Soladoye MO, Onakoya MA, Chukwuma EC, Sonibare MA (2010a). Morphometric study of the genus Senna Mill. in SouthWestern Nigeria. African Journal of Plant Science 4(3):44-52.

Soladoye MO, Sonibare MA, Chukuma EC (2010b). Morphometric study of the genus Indigofera Linn. (Leguminosae-Papillionoideae) in South-Western Nigeria. International Journal of Botany 6(3):343-350.

Sonibare MA, Jayeola AA, Egunyomi A (2004). A morphometric analysis of the genus Ficus Linn. (Moraceae). African Journal of Biotechnology 3:229-235. 